\title{
Morphometric and ultrastructural analysis of different pituitary cell populations in undernourished monkeys
}

G.M. Cónsole ${ }^{1}$, S.B. Jurado², E. Oyhenart ${ }^{3}$, C. Ferese $^{1}$, H. Pucciarelli ${ }^{3}$ and C.L.A. Gómez Dumm ${ }^{1}$

\author{
${ }^{1}$ Cátedra de H istología-Embriología "B", Facultad de Ciencias M édicas, \\ 2Servicio Central de Microscopía Electrónica, and \\ ${ }^{3}$ Centro de Investigaciones en Genética Básica y Aplicada, Facultad de Ciencias \\ Veterinarias, Universidad Nacional de La Plata, La Plata, Argentina
}

\section{Correspondence \\ G.M. Cónsole \\ Cátedra de Histología-Embriología \\ "B", Facultad de Ciencias Médicas Universidad Nacional de La Plata CC 455 \\ (1900) La Plata \\ Argentina \\ Fax: +54-221-425-0924 \\ E-mail: \\ gconsole@ atlas.med.unlp.edu.ar}

Research partially supported by Comisión de Investigaciones Científicas de la Provincia de Buenos Aires (CICBA), Consejo $\mathrm{Nacional}$ de Investigaciones Científicas y Técnicas (CO NICET), and Universidad Nacional de La Plata. G.M. Cónsole and C.L.A. Gómez Dumm are Career Researchers of CICBA. E. O yhenart and H. Pucciarelli are Career Researchers of CO NICET.

Received November 30, 1999 Accepted September 13, 2000

\section{Abstract}

Undernutrition elicited by a low-protein diet determines a marked reduction of hypophyseal activity and affects the function of the respective target organs. The objective of the present investigation was to study the ultrastructural and quantitative immunohistochemical changes of the different pituitary cell populations in undernourished monkeys that had been previously shown to have significant changes in craniofacial growth. Twenty Saimiri sciureus boliviensis monkeys of both sexes were used. The animals were born in captivity and were separated into two groups at one year of age, i.e., control and undernourished animals. The monkeys were fed ad libitum a $20 \%$ (control group) and a 10\% (experimental group) protein diet for two years. Pituitaries were processed for light and electron microscopy. The former was immunolabeled with anti-GH, -PRL, -LH, -FSH, -ACTH, and -TSH sera. Volume density and cell density were measured using an image analyzer. Quantitative immunohistochemistry revealed a decrease in these parameters with regard to somatotrophs, lactotrophs, gonadotrophs and thyrotrophs from undernourished animals compared to control ones. In these populations, the ultrastructural study showed changes suggesting compensatory hyperfunction. On the contrary, no significant changes were found in the morphometric parameters or the ultrastructure of the corticotroph population. We conclude that in undernourished monkeys the somatotroph, lactotroph, gonadotroph, and thyrotroph cell populations showed quantitative immunohistochemical changes that can be correlated with ultrastructural findings.

\section{Introduction}

In platyrrhine monkeys, undernutrition alters the growth of the neurocranial and facial functional components $(1,2)$. The areas of higher growth (nasal bones, parietal

\section{Key words}

- Pituitary gland

- Quantitative

immunohistochemistry

- Ultrastructure

- Undernutrition

- Squirrel monkeys and basioccipital bones, occipital squama, and palatomaxillary procidentia) are especially affected by undernutrition, suffering alteration in size, though not in shape $(2,3)$, and sexual dimorphic inversion. The use of this experimental model has made a signifi- 
cant contribution to longitudinal studies of growth and development, inasmuch as it is not affected by the intrinsic or extrinsic factors that modify the regular patterns of auxologic dynamics. In general, a low-protein and low-calorie diet produces a severe delay in human and laboratory animal growth. Furthermore, the amount and quality of food intake have a marked influence on the biological activity of hormones, especially growth hormone $(\mathrm{GH})(4,5)$.

The effect of undernutrition on the pituitary cell populations of the rat has been studied by our laboratory group and a postweaning low-protein diet (6) and maternal undernutrition throughout lactation (7) have been found to produce ultrastructural changes in somatotroph cells.

The secretion of pituitary hormones constitutes a complex process comprising stimulatory and inhibitory mechanisms of the pituitary as well as the action of intraglandular paracrine agents. Even though a number of studies on the effects of malnutrition on the secretion of pituitary hormones already exist, information about the morphological changes in the different cell populations of the gland in monkeys, under such conditions, is scarce. Food deprivation decreased somatostatin and GH-releasing hormone (GHRH) immunostaining in sections of the median eminence of the hypothalamus, and mRNA levels for somatostatin, GHRH and GH were also reduced (8).

In malnutrition, mechanisms of growth impairment appear to show a decrease in GH-induced generation of somatomedins and a rise in GH secretion due to a decreased negative feedback from somatomedins (9). Polkowska et al. (10) detected that chronic restriction of dietary proteins $(8 \%$ for 20 weeks) in female lambs markedly decreased the content of hypothalamic somatostatin.

Hara et al. (11), feeding rats a low-protein diet ( $8 \%$ for 30 days), showed in a quantitative morphological analysis that the average sectional areas of both prolactin
(PRL)- and GH-secreting cells were smaller in size than those in controls. This diet reduced the cell number in the subpopulations of PRL mRNA-positive cells and somatotrophs.

The purpose of the present study was to investigate the effect of undernutrition on the different pituitary cell populations in monkeys (Saimiri sciureus boliviensis), and to analyze possible quantitative immunohistochemical and ultrastructural changes.

\section{Material and Methods}

\section{Animal and specimen collection}

Ten male and 10 female Saimiri sciureus boliviensis (Cebidae) monkeys were studied. The animals were born in captivity at the Centro Argentino de Primates (CAPRIM) and after weaning ( 7 months) were raised at the Facultad de Ciencias Veterinarias de la Universidad Nacional de La Plata(CIGEBA). When the animals were one year old, they were divided into a control group and an undernourished group, both comprising 5 monkeys of each sex. The animals were fed ad libitum on a 20 and a $10 \%$ protein diet (Table 1), respectively. When they were three years old, radiographs were taken in order to measure the neurocranial and facial components. Thereafter, the monkeys were weighed and sacrificed by decapitation under ether anesthesia. The skulls were opened and the brains were removed and weighed. The pituitary glands were dissected out and processed for microscopic study. Maintenance and treatment of the animals were according to the National Institutes of Health Guide for Care and Use of Laboratory Animals.

\section{Immunohistochemistry and morphometry}

Pituitaries from all the animals were fixed in Bouin's fluid and embedded in paraffin. Serial sections of $4 \mu \mathrm{m}$ were obtained at different levels of the blocks following a 
ventral-to-dorsal sequence. Briefly, sections were incubated for $1 \mathrm{~h}$ at room temperature with primary anti-GH, -PRL, -FSH, -LH, -TSH, and -ACTH antibodies (mouse-Dako, Dako Corp., Carpinteria, CA, USA) diluted 1:200. Thoroughly washed sections were treated for $30 \mathrm{~min}$ with a ready-to-use EnVision reaction system (Dako). The peroxide-sensitive chromogen was diaminobenzidine. The specificity of the primary antiserum was monitored either by the ability to block the immunohistochemical reaction by preadsorption of the antibody with an excess of the related antigen or by replacing the first antiserum with normal rabbit serum or PBS.

Measurements of cell parameters were made using an image-analysis system (Optimas 5.2, Imaging Technology Inc., Bedford, MA, USA). The immunostained cells and reference area were analyzed for each field for an average of 10 micrographs taken from different levels (ventral, medial, and dorsal). These measurements were recorded, processed automatically, and finally used to calculate the following parameters: volume density $(\mathrm{VD}=$ cell area/reference area, RA) and cell density ( $C D=$ number of cells/RA). RA represents the adenohypophyseal (pars distalis) area scanned, in which pituitary cells were scored. Then, with the sum of the individual areas referred to as RA, we obtained VD, which indicates cell mass according to a usually accepted concept. CD represents the number of pituitary cells referred to as RA.

\section{Conventional electron microscopy}

Pituitary glands from 4 animals of each group were used. The anterior lobe (lateral wings) was dissected and fixed in $2 \%$ glutaraldehyde in $0.05 \mathrm{M}$ cacodylate buffer. The material was cut into small pieces $(1 \mathrm{x} 1$ $\mathrm{mm}$ ), postfixed in $1 \%$ osmium tetroxide and embedded in Araldite. Thick sections (about $1 \mu \mathrm{m}$ ) were stained with toluidine blue and observed by light microscopy in order to select fields. Ultrathin sections were mounted on copper grids, stained with uranyl acetate and lead citrate, and examined with a JEM1200 EX transmission electron microscope at $80 \mathrm{kV}$.

\section{Statistical analysis}

Statistical evaluation was performed by one-way analysis of variance, followed by the least significant difference (LSD) test for multiple comparisons. Data are reported as mean \pm SEM.

\section{Results}

\section{Immunohistochemical and histometric studies}

Immunolabeled pituitary cells exhibited an ochre granular cytoplasmic pattern. A decline in the number (Figure 1) of somatotroph $(\mathrm{a}, \mathrm{b})$, lactotroph $(\mathrm{c}, \mathrm{d})$, gonadotroph $(e, f)$ and thyrotroph $(g, h)$ cell populations of undernourished monkeys of both sexes was evident even before the quantitative evaluation. No morphological changes were found in the corticotroph cells (Figure 1i,j). Analysis of VD and CD (Figures 2 to 4 ) showed that these parameters were significantly $(\mathrm{P}<0.05)$ diminished in undernourished monkeys in terms of GH, PRL, FSH, LH and

\begin{tabular}{|c|c|c|}
\hline Component & $\begin{array}{l}\text { Control } \\
\text { diet }(g)\end{array}$ & $\begin{array}{l}\text { Low-protein } \\
\text { diet (g) }\end{array}$ \\
\hline Soybean meal & 28.0 & 9.9 \\
\hline Wheat meal & 14.7 & 8.0 \\
\hline Glucose & 0.0 & 6.7 \\
\hline Skim milk & 10.6 & 4.9 \\
\hline Wheat bran & 5.6 & 5.6 \\
\hline Saccharose & 3.5 & 3.5 \\
\hline Rice meal & 3.3 & 6.6 \\
\hline Corn starch & 3.0 & 21.4 \\
\hline Margarine & 4.2 & 6.7 \\
\hline Egg & 7.0 & 3.2 \\
\hline Vitamin mixture & 1.5 & 1.5 \\
\hline
\end{tabular}


Figure 1 - Representative fields of specifically immunostained pituitary cells. Somatotroph cells from male control (a) and male undernourished (b) groups. Lactotroph cells from female control (c) and female undernourished (d) groups. Gonadotroph cells from male control (e) and male undernourished (f) groups. Thyrotroph cells from male control (g) and male undernourished (h) groups. Corticotroph cells from male control (i) and male undernourished (j) groups. EnVision system peroxidase (200X). Magnification bar: 10 $\mu \mathrm{m}$.
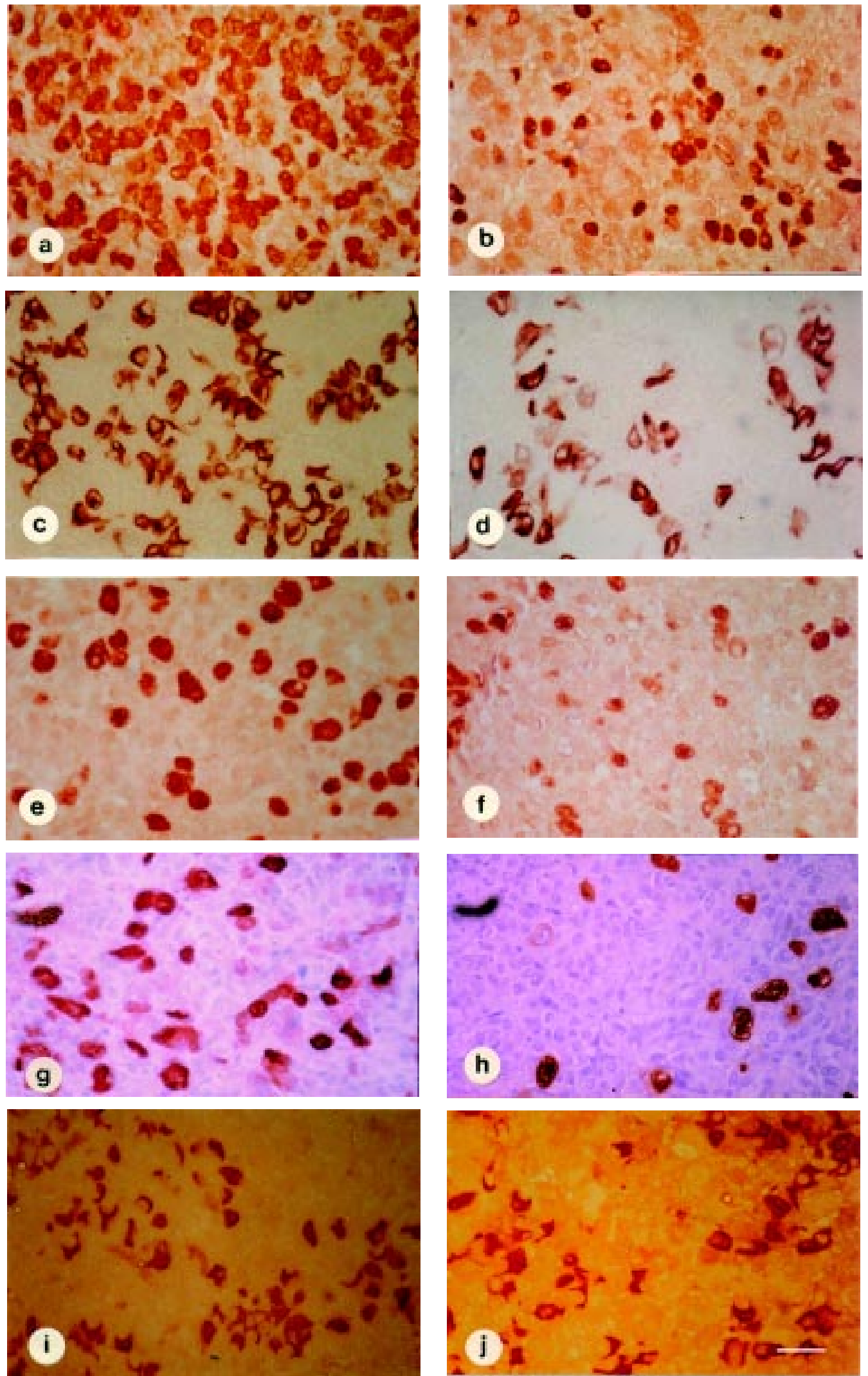
TSH cells compared to control ones of both sexes. On the contrary, no significant differences were detected in the VD and CD of the ACTH cell population.

Percent distribution showed a significant $(\mathrm{P}<0.05)$ decrease of somatotroph, lactotroph, gonadotroph and thyrotroph populations, with a nonsignificant increment of the corticotroph population of malnourished animals of both sexes compared to controls. Cell mass compensation was due to a significant $(\mathrm{P}<0.05)$ increment in the chromophobe population (no immunolabeled cells) (Table 2).

\section{Ultrastructural study}

A qualitative evaluation by electron microscopy revealed that many somatotroph, lactotroph, gonadotroph and thyrotroph cells from undernourished monkeys exhibited similar changes, which were only eventually found in control animals. The GH cells from undernourished monkeys (Figure 5) showed an expanded and dilated Golgi complex and a decrease in the number of round and large (250-400 nm) secretory granules with exocytotic profiles. The PRL cells from undernourished animals (Figure $6 \mathrm{a}, \mathrm{b}$ ) exhibited a hypertrophic Golgi complex with immature secretory material. Scarce peripheral pleomorphic secretory granules ranging from 100 to $600 \mathrm{~nm}$ and irregular rough endoplasmic reticulum were seen. Some of these lactotroph cells showed long cytoplasmic crystalloids related to lipid inclusions.

Gonadotroph cells from the undernourished group (Figure 7) contained an expanded and dilated rough endoplasmic reticulum as well as peripheral secretory granules, some of them in contact with the plasma membrane. Thyrotroph cells of the same group (Figure 8) showed irregular rough endoplasmic reticulum with abundant polyribosomes. Small peripheral secretory granules were also observed. The corticotroph cells of undernourished animals (Figure 9) presented nor-

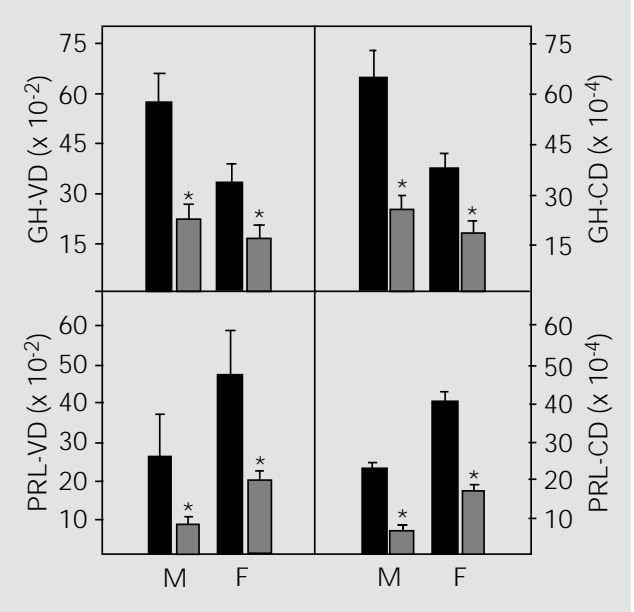

Figure 2 - Volume density (VD) and cell density (CD) of GH and $P R L$ cell populations in male (M) and female $(F)$ monkeys from the control (black bars) and undernourished (gray bars) groups. $* \mathrm{P}<0.05$ compared to control (LSD test for multiple comparisons).

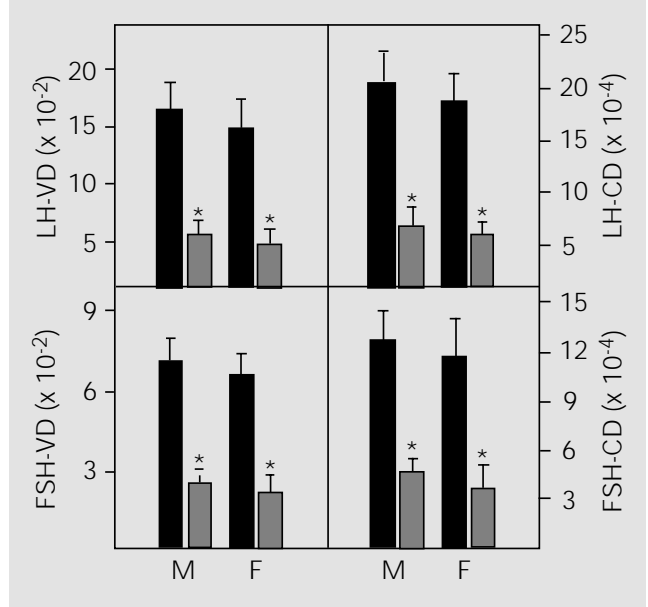

Figure 3 - Volume density (VD) and cell density (CD) of $\mathrm{LH}$ and FSH cell populations in male (M) and female (F) monkeys from the control (black bars) and undernourished (gray bars) groups. $* \mathrm{P}<0.05$ compared to control (LSD test for multiple comparisons).

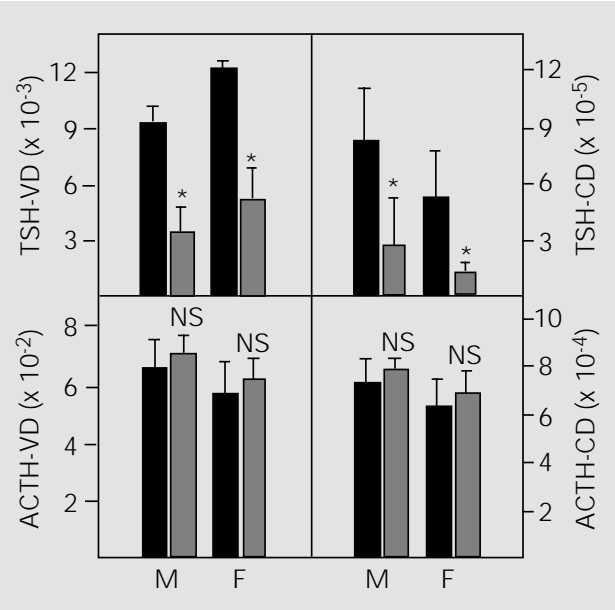

Figure 4 - Volume density (VD) and cell density (CD) of TSH and ACTH cell populations in male (M) and female (F) monkeys from the control (black bars) and undernourished (gray bars) groups. $* \mathrm{P}<0.05$ compared to control (LSD test for multiple comparisons). NS, Nonsignificant. 
mal characteristics when compared to the control group.

\section{Discussion}

The present quantitative immunohistochemical results showed a significant decrease in the somatotroph population from undernourished monkeys, that correlated well with the alterations described by Medvedev et al. (12) in the morphometric analysis of the somatotrophs of mice submitted to protein energy insufficiency ( $5 \%$ for 20 days).
These investigators detected a marked decrease in the cell number and volume of the cytoplasm. In agreement with our results, Herbert et al. (13) detected a significantly reduced number of somatotrophs in rats as a result of a low-protein diet.

GH is described as an anabolic, lipolytic and insulin antagonist that facilitates the best use of nutrients during deprivation periods (14). Age and nutritional status have been found to determine variations in the secreting patterns of this hormone $(14,15)$. The pulsatile administration of GH to GH-defi-

Table 2 - Percent distribution (\% volume density) of the different pituitary cell populations in undernourished and control monkeys.

NS: Nonsignificant; *P<0.05 compared to control of the same sex (LSD test for multiple comparisons).

\begin{tabular}{lcccc}
\hline Cells & Male control & Male undernourished & Female control & Female undernourished \\
\hline GH & 26.7 & $9.7^{*}$ & 16.4 & $6.7^{*}$ \\
PRL & 12.3 & $4.0^{*}$ & 23.0 & $7.9^{*}$ \\
LH & 7.7 & $2.4^{*}$ & 7.3 & $1.9^{*}$ \\
FSH & 3.3 & $1.1^{*}$ & 3.2 & $0.8^{*}$ \\
TSH & 0.4 & $0.2^{*}$ & 0.6 & $0.2^{*}$ \\
ACTH & 3.1 & $3.1 \mathrm{NS}$ & 2.8 & $2.5 \mathrm{NS}$ \\
Chromophobes & 46.4 & $79.5^{*}$ & 46.9 & $79.9^{*}$
\end{tabular}

Figure 5 - Electron micrograph of a GH cell from an undernourished monkey showing an expanded and dilated Golgi complex (G). Several secretory granules are contacting the plasma membrane (arrows) (18,000X).

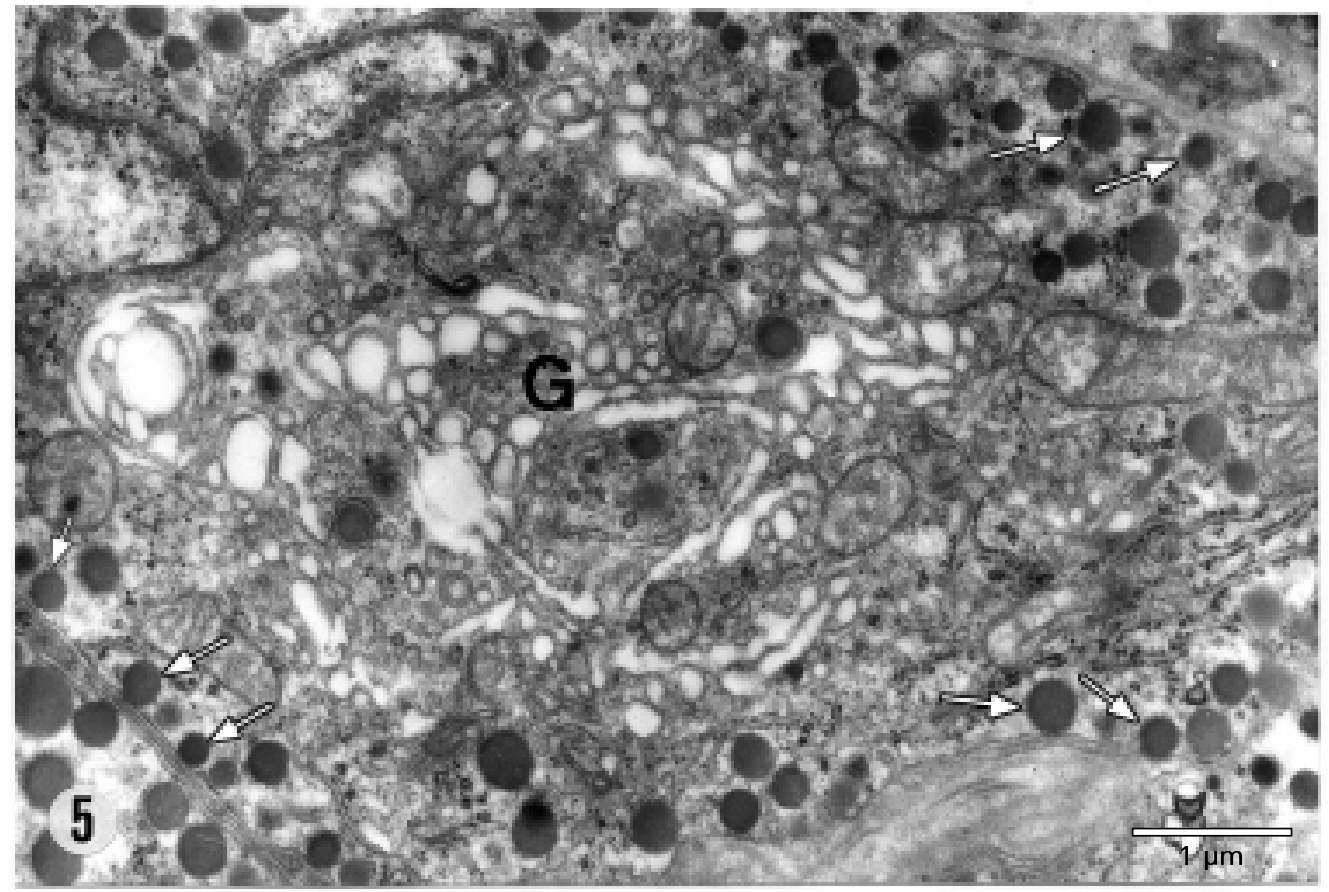


cient adults causes significant alterations in protein, carbohydrate and lipid metabolism, supporting the hypothesis that $\mathrm{GH}$ plays an important role in the utilization of nutrients (15). On the other hand, biochemical data have shown reduced GH levels (16), to- gether with a lesser serum activity of somatomedins (17), in undernourished rats.

In our histometric study, the VD and CD revealed a significant decrease of the lactotroph population in undernourished monkeys submitted to experimental undernutri-
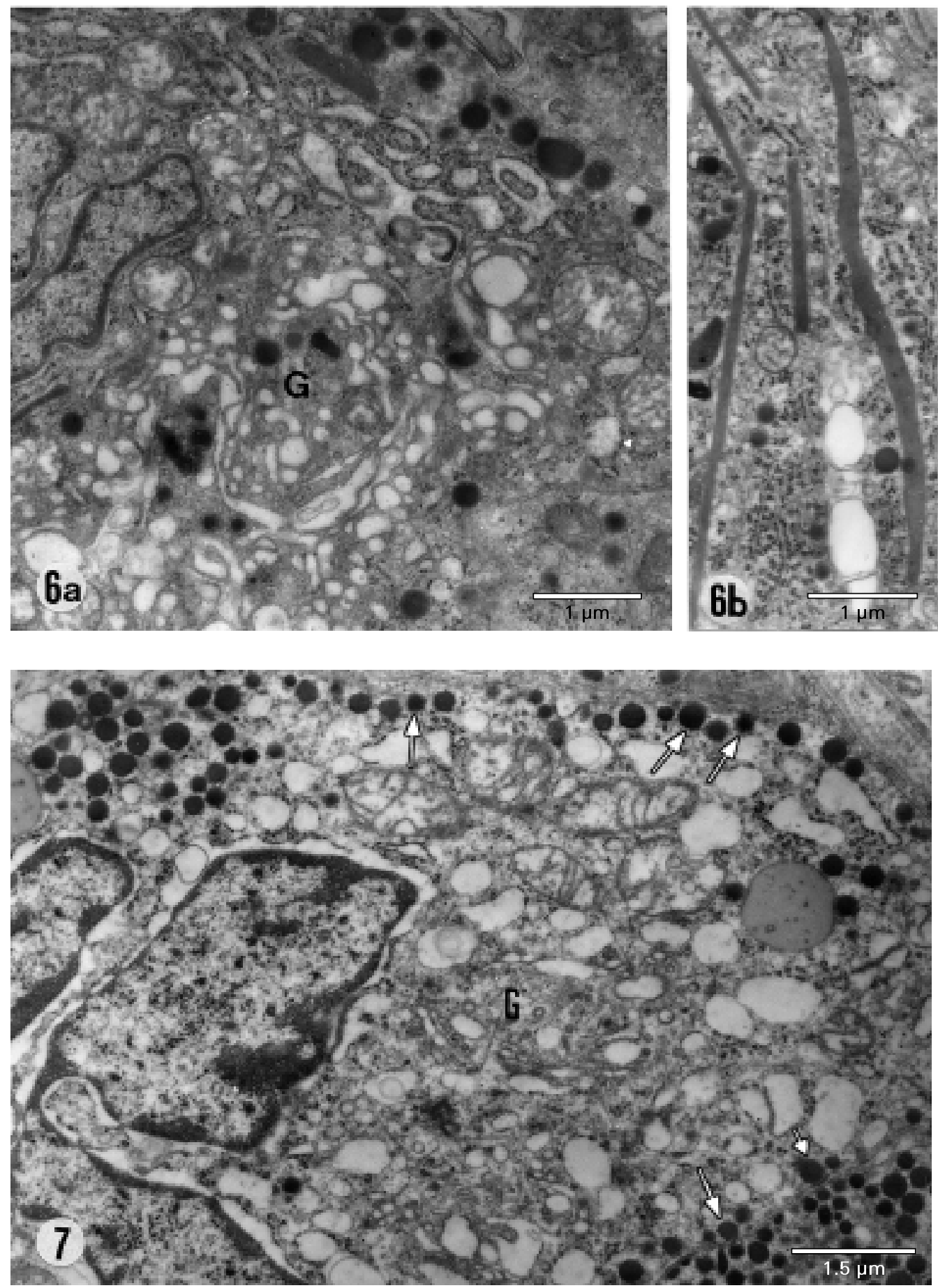

Figure 6 - Electron micrographs of a PRL cell from an undernourished animal exhibiting a hypertrophic Golgi complex (G) with immature secretory material (a). Peripheral granules and irregular rough endoplasmic reticulum are seen in the right upper comer $(18,000 \mathrm{X})$; b, long cytoplasmic crystalloids (18,000X).
Figure 7 - Electron micrograph of an FSH cell from an undernourished monkey containing an expanded and dilated rough endoplasmic reticulum as well as peripheral secretory granules, some of them in contact with the plasma membrane (arrows). The Golgi zone (G) is also seen (13,000X). 
tion, showing sex dimorphism. In a quantitative morphological analysis, Hara et al. (11), feeding rats a low-protein diet $(8 \%$ for 30 days), showed that the average sectional areas of both PRL- and GH-secreting cells were smaller in size than those of controls.
Regarding the gonadotroph population, age and nutritional status determine variations in the secreting patterns of gonadotrophins (18). Thus, we have found a decrease of the gonadotroph population in undernourished monkeys in agreement with the alter-

Figure 8 - Electron micrograph of a TSH cell from an undernourished animal showing irregular rough endoplasmic reticulum with abundant polyribosomes. Small peripheral secretory granules are also observed $(24,000 \mathrm{X})$.

Figure 9 - Electron micrograph of an ACTH cell (asterisk) with normal characteristics $(10,000 X)$.
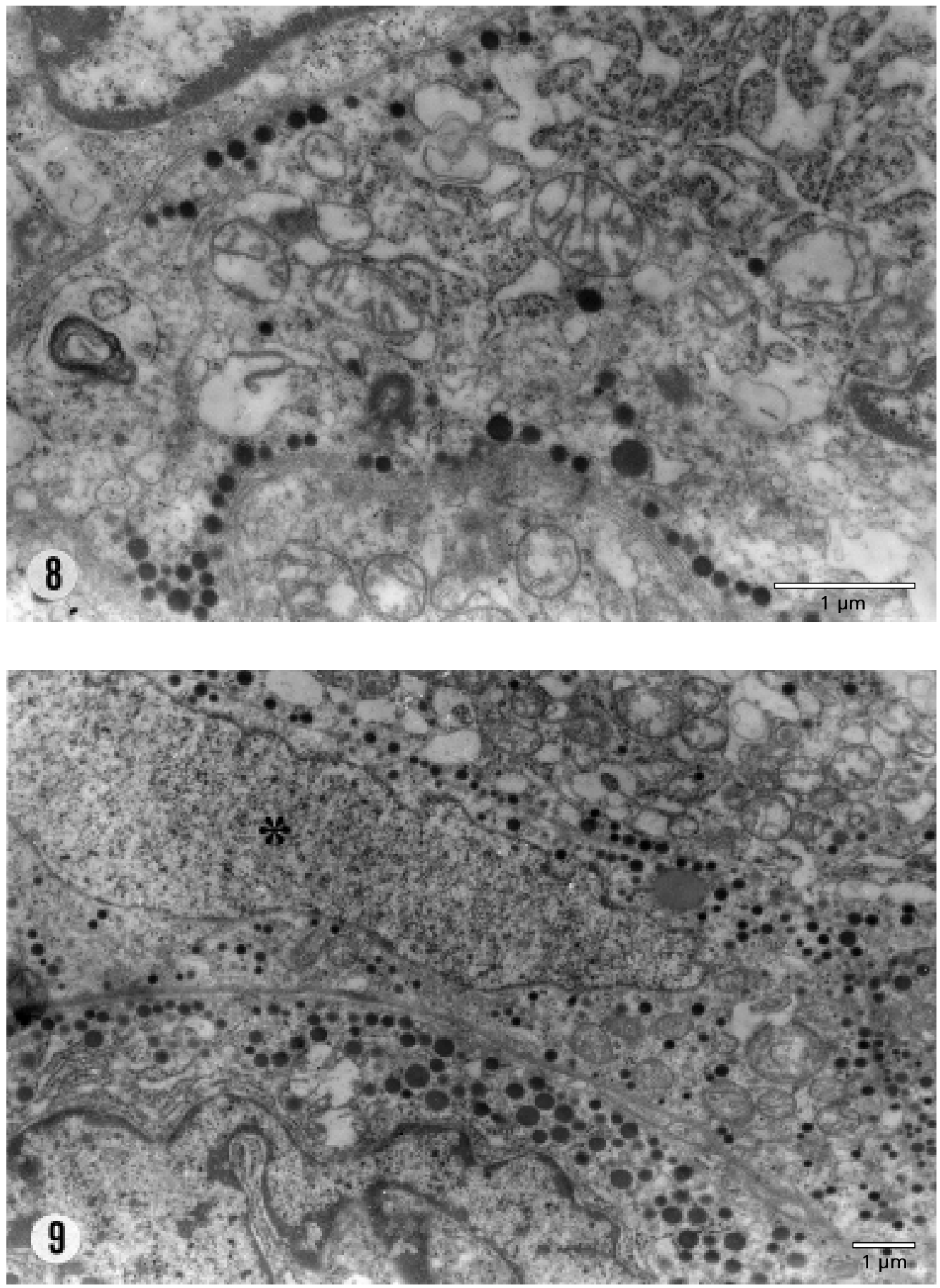
ations described in such population from undernourished rats $(18,19)$.

On the other hand, it is worth mentioning that Herbert and Carrillo (20) found an increment in the corticotroph population suggestive of a stimulation of the hypothalamus-hypophyseal-adrenal axis, induced by the protein-calorie undernutrition. However, the stereologic parameters presently used showed no significant changes in such cell population.

The percent increment of somatotroph, lactotroph, gonadotroph, and thyrotroph cell populations, with nonsignificant changes in the corticotroph group, may be associated with an increment of the chromophobe population comprising both immature forms with scarce secretory granules and degranulated involutive cells.

The ultrastructure of GH-, PRL-, LH-, FSH- and TSH-secreting cells allowed us to observe a reduction of secretory granules with higher exocytotic activity, together with an expanded rough endoplasmic reticulum and Golgi complex. Medvedev et al. (12) detected by electron microscopy a diminution of the mean diameter of the secretory granules of somatotrophs of mice on a lowprotein diet. From an ultrastructural point of view, Herbert (18) described a less extensive granular endoplasmic reticulum and Golgi complex in undernourished male rats. The number of secretory granules was not different; however, they were markedly smaller, while their shape was round to ovoid, rather than pleomorphic. This would imply an attempt to release a compensatory higher amount of secretory material, suggesting a hyperstimulation pattern.

The immunohistochemical and ultrastructural findings presently described in the different pituitary populations of undernourished monkeys correlate well with changes reported in undernourished rats (6-8).

It is known that in squirrel monkeys undernutrition caused by a low-protein diet produces a decrease in body and skull size, but not in brain weight, which was supported by the craniofacial morphometric patterns previously described by our group $(1,21)$.

Sex dimorphism detected in GH- and PRL-cell populations was correlated with craniofacial morphometric patterns of undernourished monkeys when compared with controls. Similar results were found in rats $(18,22-24)$ and men (25). This fact may be explained by the "better canalization hypothesis" postulated by Tanner (26), whereby it is more difficult to deviate females than males from their own growth canals, even though the nutritional environment is the same for both sexes.

Undernutrition determined a decrease in the pituitary GH-, PRL-, FSH-, LH-, and TSH-cell mass due to a diminution of the cell number that can be correlated with our ultrastructural observations.

\section{Acknowledgments}

The authors are grateful to Ms. María Bracamonte, Ms. Gabriela Simonetto, Ms. Bibiana Orden, and Ms. María C. Muñe for technical assistance.

\section{References}

1. Pucciarelli HM, Dressino $\mathrm{V} \&$ N Niveiro $\mathrm{MH}$ (1990). Changes in skull components of the squirrel monkey evoked by growth and malnutrition: An experimental study. American J ournal of Physical Anthropology, 81: 535-544.

2. Pucciarelli HM \& Dressino V (1996). Ortocephalization on the postweaning squirrel monkey. American J ournal of Physical Anthropology, 101: 173-181.

3. Corner BD \& Richstmeier J T (1992). Cranial growth in squirrel monkey (Saimiri sciureus): a quantitative analysis using three dimensional coordinate data. American J ournal of Physical Anthropology, 87: 67-82.
4. Cheek DB \& Hill DE (1974). Effect of growth hormone on cell and somatic growth. In: Greep A (Editor), Handbook of Physiology (Endocrinology). Vol. 4. Waverly, Baltimore, 159-183.

5. Pimstone BL (1976). Endocrine function in protein calorie malnutrition. Clinical Endocrinology, 5: 79-95. 
6. Gómez Dumm CLA, Pucciarelli HM \& Terreros MC (1982). Effects of a low-protein diet on the ultrastructure of somatotroph cells in the rat. Comunicaciones Biológicas, 1: 165-170.

7. Gómez Dumm CLA, Pucciarelli HM \& Dressino V (1987). Quantitative ultrastructural study of somatotropic cells in undernourished weanling rats. Acta Anatomica, 129: 200-202.

8. Brogan RS, Fife SK, Conley LK, Giustina A $\&$ Wehrenberg WB (1997). Effects of food deprivation on the $\mathrm{GH}$ axis: immunocytochemical and molecular analysis. Neuroendocrinology, 65: 129-135.

9. Phillips LS (1986). Nutrition, somatomedins, and the brain. Metabolism, 35: 7887.

10. Polkowska J, Krejci P \& Snochowski M (1996). The long-term effect of low protein diet on the somatostatin hypothalamic neuronal system and the pituitary growth hormone cells in growing ewe. Experimental and Clinical Endocrinology and Diabetes, 104: 59-66.

11. Hara M, Herbert DC, Taniguchi T, Hattori A, Ohtani-Kaneko $R$, ligo $M$, Kato $Y \&$ Hirata K (1998). Effects of a low-protein diet on prolactin- and growth hormoneproducing cells in the rat pituitary gland. Anatomical Record, 251: 37-43.

12. Medvedev DI, Babichenko II, Savrova OB, Eremia IZ\& Kravtsova AI (1995). The morphological state of the adenohypophyseal somatotrophs during body development under conditions of protein-energy insuf- ficiency. Aviakosmicheskaia I Ekologicheskaia Medtsina, 29: 28-31.

13. Herbert DC, Yashiro T, Muraki T, Okano T, Hattori A \& Suzuki T (1993). Quantitative morphological analysis of the pituitary gland in protein-calorie malnourished rats. Anatomical Record, 235: 121-125.

14. Snyder DK, Clemmons DR \& Underwood LE (1988). Treatment of obese, diet-restricted subjects with growth hormone for 11 weeks: Effects on anabolism, lipolysis and body composition. J ournal of Clinical Endocrinology and Metabolism, 67: 54-61.

15. Lee Vance $M$, Hartman $M L \&$ Thomer MO (1992). Growth hormone and nutrition. Hormone Research, 38 (Suppl 1): 8588.

16. Nitzan M \& Wilber IF (1974). Effect of postnatal malnutrition on plasma proteins and growth hormone in the rat. Hormone Research, 5: 167-172.

17. Price DA, Wit JM, Van Buul-Offers $S$, Korteland-van Male AM, van RooyenWehrneijer AKM, Hoogerbrugge $C \&$ Van den Brande J L (1979). Serum somatomedin activity and cartilage metabolism in acutely fasted, chronically undernourished, and refed rats. Endocrinology, 105: 851-861.

18. Herbert DC (1980). Morphology of the mammotrophs and gonadotrophs in the anterior pituitary gland of rats with protein-caloric malnutrition. American J ournal of Anatomy, 158: 521-531.

19. Heindel JJ, Berkowitz AS, Grotjan HE,
Herbert DC, Klemckes HG \& Bartke A (1988). Pituitary and testicular function in the restricted (Hre) rat. International J ournal of Andrology, 11: 313-326.

20. Herbert DC \& Carrillo AJ (1982). The hypophyseal-adrenal axis in the protein-calorie undernourished rat. Hormone and Metabolic Research, 14: 205-207.

21. Dressino V \& Pucciarelli HM (1997). Cranial growth in Saimiri sciureus (Cebidae) and its alteration by nutritional factors: A longitudinal study. American J ournal of Physical Anthropology, 102: 545-554.

22. Pucciarelli HM (1980). The effects of race, sex, and nutrition on craniofacial differentiation in rats. A multivariate analysis. American J ournal of Physical Anthropology, 53: 359-368.

23. Pucciarelli HM (1981). Growth of the functional components of the rat skull and its alteration by nutritional effects. A multivariate analysis. American J ournal of Physical Anthropology, 56: 33-41.

24. Oyhenart EE \& Pucciarelli HM (1992). Sexual cranial dimorphism in undernourished rats treated with growth hormone. Growth, Development, and Aging, 56: 179-184.

25. Pucciarelli HM, Camese FR, Pinotti LV, Guimarey LM \& Goicoechea AS (1993). Sexual dimorphism in schoolchildren of the Villa IAPI neighborhood (Quilmes, Buenos Aires, Argentina). American J ournal of Physical Anthropology, 92: 165-172.

26. Tanner J M (1962). Growth at Adolescence. Blackwell, Oxford. 